\title{
Growth and Ripening of Globe Artichoke Achens
}

\author{
Yehuda Basnizki* \\ Department of Ecology, Systematics and Evolution, The Hebrew University of Jerusalem \\ Givat Ram, 91904 Jerusalem
}

Received: 5 May 2007. Accepted: 9 September 2007.

\begin{abstract}
Under dry summer eastern Mediterranean conditions, the growth and ripening of seeds (from flowering onward) can proceed without supply of water. The leaves and capitule bearing stems dry out while the receptacles stay moist and allow seed ripening. The functioning of the various capitule components was examined.
\end{abstract}

Key-words: Cynara scolymus L., achens, ecodormancy, capitule, physiological maturity, Inulin, Chlorogenic acid.

\section{Introduction}

The Globe Artichoke (Cynara scolymus L.) is a herbaceous, perennial, rosette forming plant domesticated in the Mediterranean area. It reflects the environmental conditions of this region. (Basnizki, 1979; Basnizki, 1985). It is grown for its young edible inflorescences (capitules) which grow on primary or higher order stems. If it is not harvested for consumption it continues to grow and produces normal "seed" (Globe Artichoke "seeds" are dry fruits called achens). Globe Artichoke is largely cross pollinated, allogamy is controlled by protandry. Flowering is centripetal, honey bees are the principal pollination vector (Foury, 1967). Perennial growth is secured by axillary buds of the short subterranean stem which develop small rosettes with a root system (La Malfa, 1967; Bianco and Pimpini, 1990). The eastern Mediterranean summer is rainless, has elevated evapotranspiration, restricted available soil water and intense solar radiation. This climatic syndrom causes heat induced ecodormancy during which all aerial parts of the plant dry out, including the rosette leaves of the subterranean buds. The younger leaves sclerify to protect the shoot apex. In spite of these climatic conditions, Globe Artichokes produce normal seeds. The present study examined this adaptation.

\section{Materials and methods}

The trial was conducted at the experimental station of the Hebrew University at Talpiot, Jerusalem. In 1988 a single row of the seed grown line HU 251 was sown directly into the soil. The agrotechnical treatment of this row was similar to treatments of other seed grown Globe Artichoke varieties at this station. Flowering begun in May, pollination was by honeybees from a bee hive. Prior to pollination, capitules with short peduncles were placed in a jar which contained a stain solution of $0.1 \%$ Eosin (Erytrosin) to detect water in the different components of the capitule. In a separate check the interfloral hairs were stained in Neutral Red for $24 \mathrm{~h}$ to verify if they are living tissues. Examination of the hairs under a microscope showed stain in bundles of long cells, indicating that the hairs are living. Pollinated capitules were sampled from the end of June until mid August, their scales were examined for stomata, fresh

\footnotetext{
* Corresponding Author: Tel.: +972 8 9489230; Fax: +972 8 9466267. E-mail-address: iuda@netvision.net.il
} 
seeds from capitules of each order (see below) were weighted. The pappus, style, seed, interfloral hairs and receptacles were separately oven dried at $105{ }^{\circ} \mathrm{C}$ in 5 replications of 10 units per component. Results are given as \% humidity on dry matter basis.

\section{Results and discussion}

\subsection{Patterns of capitule formation}

Upon germination, Globe Artichoke seedlings produce a tap root and several secondary roots. The subterranean stem is short and bears a rosette of large leaves. In spring the secondary roots thicken and become storage roots, the short subterranean stem thickens too and its eldest axillary buds develop rooted shoots to secure perennial growth (Bianco and Pimpini, 1990; La Malfa, 1967).

The reproductive apex of the capitule and its content in nutrients were already described by Bianco and Pimpini (1990) and by Di Venere et al. (2005). Significantly, the uppermost part of the receptacle contains well staining cells which house the florets and interfloral hairs.

Globe Artichokes follow a regular pattern of flowering. The first capitule grows on the central stem with bears relatively large leaves and is called the "Main" capitule. Several internodes beneath the main capitule, the first stem emits up to 3 ramifications, each of these is terminated by a $2^{\text {nd }}$ order, smaller capitule. Often these stems are longer than the central stem, their leaves are relatively smaller. Several internodes beneath the $2^{\text {nd }}$ order capitule a smaller ramification develops from the $2^{\text {nd }}$ order stem which bears fewer, simple shaped, smaller leaves and terminates by a yet smaller $3^{\text {rd }}$ order capitule. The leaves of the stems and the bracts of the capitules have stomata at their upper and lower sides which allow gas exchange. In other words, each capitule is fit to produce photosynthats.

\subsection{Seed growth in the various orders of capitules}

The growth of Globe Artichoke achens is given in table 1. At the first sampling date the average fresh weight of main capitule seeds was higher than in $2^{\text {nd }}$ and $3^{\text {rd }}$ order capitules. These differences can result from successive flowering times, the main capitule flowers about three weeks before $3^{\text {rd }}$ order capitules. The link be-
Table 1. Increase of seed weight in three orders of capitules.

\begin{tabular}{lccc}
\hline $\begin{array}{l}\text { Sampling } \\
\text { Date }\end{array}$ & $\begin{array}{c}\text { Main } \\
\text { capitule }\end{array}$ & $\begin{array}{c}2^{\text {end }} \text { order } \\
\text { capitule }\end{array}$ & $\begin{array}{c}3^{\text {rd }} \text { order } \\
\text { capitule }\end{array}$ \\
\hline 01 July & $44 \pm 6$ & $26 \pm 7$ & $31 \pm 7$ \\
18 July & $47 \pm 3$ & $39 \pm 2$ & $42 \pm 4$ \\
01 Aug. & $49 \pm 1$ & $52 \pm 1$ & $48 \pm 3$ \\
\hline
\end{tabular}

tween flowering time and seed growth can be seen in the late flowering $3^{\text {rd }}$ order capitule where seeds have not yet reached their final weight at the last sampling date. The standard deviations of all orders suggest that the absorption of liquid nutrients is more intensive at the beginning of seed growth, afterwards it continues at a slower pace until final weight. In this study the average final weight of seed from all orders was ca. $50 \mathrm{mgr} \cdot \mathrm{seed}^{-1}$. In other cultivars it could by higher or lower.

\subsection{Seed ripening}

Foury (1987) followed up the anatomical developments from ovary to fruit. In brief, his data shows that fertilization occurs $18-24 \mathrm{~h}$ from pollination. The initials of the cotyledons become visible 6-8 days later, they continue to grow for the next 25 days. During the growth of the cotyledons, the formation of the pericarp is relatively delayed, from thereon its cell walls begin to thicken, to lignify and to produce pigmentation.

The present study shows that the water content of the capitule components decreases in accordance with their function in the system (Fig. 1 ). The style ends its function when the pollen tube reaches the microphylle which occures18$24 \mathrm{~h}$ after pollination (Foury, 1987). The pappus is caducous hence does not contribute to seed dispersal and desiccates. In other words, when a capitule component has ended its task it gradually dries out.

Two weeks after pollination the seeds contain more water indicating that they probably still absorb nutrients. From hereon theel with the water content of the seeds. When the seeds reach "physiological maturity" the importance of cooling by hairs lessens because the pericarp now provides more appropriate isolation. From thereon they desiccate gradually, they bend over the seeds and create an aerated network of hairs that shades the seeds.

During 26 days from pollination the recep- 


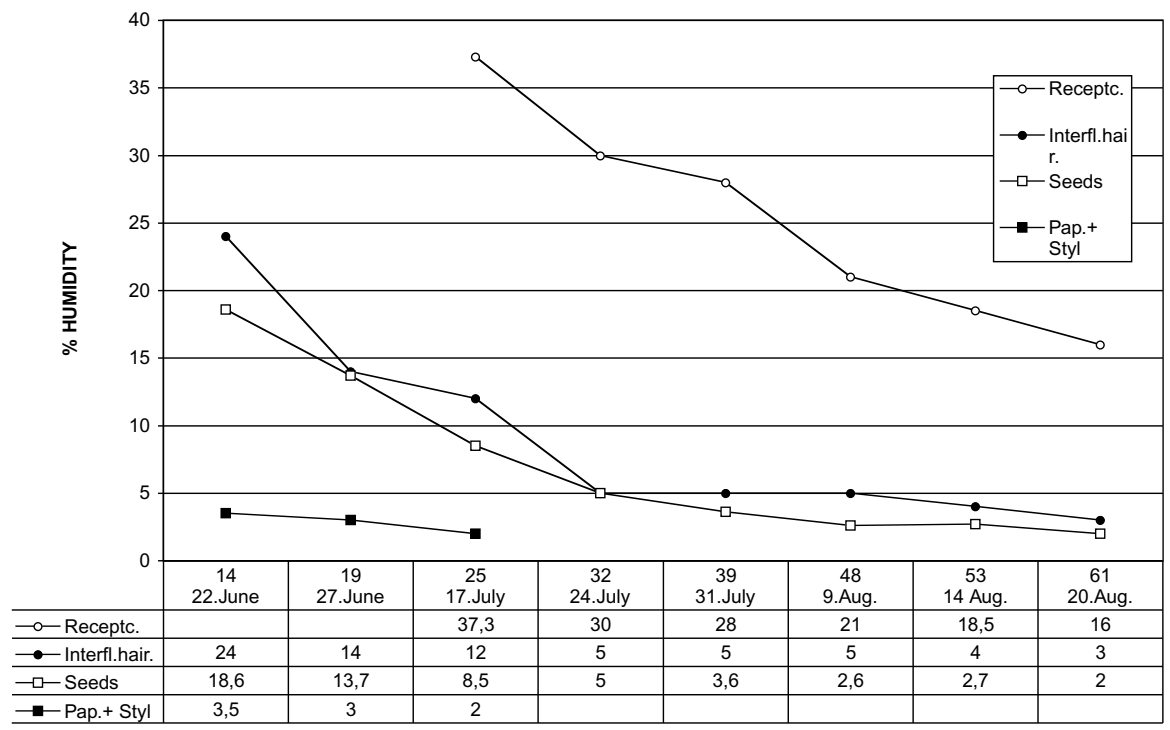

DAYS AND DATES FROM POLLINATION
Figure 1. Changes in humidity of capitule components during seed ripening. tacle contained more moisture than other capitule components. From thereon its moisture content decreases, after two months it becomes fibrous and holds the deeply anchored seeds and interfloral hairs. For example: In wild $C y$ nara syriaca Boiss., a taxon endemic to the east Mediterranean area, dry capitules (with seed and interfloral hairs contained in them) still exist in October, before the rainy season starts.

\section{Conclusions}

The present study shows that Globe Artichoke achens absorb nutrients from the receptacle. About five weeks after pollination the seeds reach physiological maturity and can germinate. The elevated temperatures during seed growth can be moderated by cooling from interfloral hairs which in turn absorb fluids from the receptacle. Among the many chemical compounds produced and stored in the inner bracts and receptacles are chlorogenic acid and "Cynarine" (1,5 dicaffeoyil quinic acid). The highest concentration of the two latter is in the seeds (Della Gatta and Patruno, 1976). This is in line with the results of the present investigation: growing Globe Artichoke achens absorb and store chemicals in the cotyledons, they do not produce them.

It appears that the Globe Artichoke capitule is a very sophisticated structure, each part of it is aimed to create appropriate conditions for seed development. When these tasks are fulfilled they dry out. From the ecological point of view the late flowering of wild Cynara taxa and similar members of the Sunflower family can be important for the coexistence with pollinators since they can be late sources of pollen and nectar.

\section{References}

Basnizki Y., Even Ari M. 1974. Effects of a reflectant on leaf temperature and development of Globe Artichoke (Cynara scolymus L). J. Amer. Soc. Hort. Sci., 100, 2:112-115.

Basnizki Y., Gil J. 1979. Effect of a reflectant spray on the water balance and yield of dry farmed cotton. Hasadeh, 5:873-876 (Hebrew with English summary).

Basnizki Y. 1981. Éxigeances eco-physiologiques communes à l'Artichaut (Cynara scolymus L) et aux Cynara sauvage. $3^{\text {rd }}$ World Congress on Artichoke, Bari 1979. Ed. Ind. Grafica Laterza, Bari.

Basnizki Y. 1985. Cynara scolymus. In: Halevy A.E. (ed.): Handbook of flowering. Vol. 2. CRC Press Inc. Bocca Raton. Fl. (USA).

Bianco V.V., Pimpini F. 1990. Carciofo. In: Orticultura. Pàtron, Bologna.

Della Gatta C., Patruno A. 1976. Il contenuto in ortodifenoli nei capolini di carciofo. In: Nuovi studi sul carciofo. $2^{\text {nd }}$ Int. Cong. on Artichoke. Bari. Minerva Medica, Torino.

Di Venere D. et al. 2005. Morphological and biochemical changes during growth and development of Artichoke buds. In: Bianco V.V. et al. (eds.): Acta Horticulturæ. Proc. $4^{\text {th }}$ I.C. on Artichoke, Vol. 681. ISHS. 
Dornbos D., Dornbos L. Jr. 1995. Seed vigor. In: Amarjit S. Basra (ed.): Seed quality. Basic mechanisms and agricultural implications. Ph.D. Food product press. The Harworth Press. Inc.

Foury C. 1967. Étude de la biologie florale de l'artichaut (Cynara scolymus L.) Application à la sélection. $1^{\text {re }}$ Partie: Données sur la biologie florale. Ann. Amélior. plantes., 17, 4:357-373.

Foury C. 1987. Quelques aspects du dévelopment de l'artichaut (Cynara scolymus L.) issue de semence; analyse plus particulière de la floraison en condition naturelles. Ph.D. Thesis, Universitée Pierre et Marie Curie, Paris IV.

La Malfa G. 1967. Ricerche sulla differenziazione degli organi di moltiplicazione del carciofo (Cynara scolymus L.). $1^{\text {st }}$ Int. World Congr. on Artichokes. University of Bari 1967. Ed. Tipografia Minerva Medica, Torino. 